\title{
Dna Laddering, Rt-Pcr and in Silico Interaction Studies for Aqueous Leaf Extracts of Ipomoea Sepiaria as Anticancer Agents Towards Pc-3 Cell Lines
}

\author{
Sudhakar Meesala ${ }^{1}{ }^{*}$ Satyanarayana Rentala ${ }^{2}$, DSVGK Kaladhar ${ }^{3}$ \\ ${ }^{1}$ Department of Biotechnology, JNTUH, Hyderabad \\ ${ }^{2}$ Department of Biotechnology, GITAM University, Visakhapatnam - 530045 \\ ${ }^{3}$ Dept. of Microbiology and Bioinformatics, Bilaspur University, Bilaspur (CG)-495001
}

*Corresponding Author: Sudhakar Meesala, Department of Biotechnology, JNTUH, Hyderabad

\begin{abstract}
Apoptosis is a process of programmed cell death ( $p c d)$ involved in the cellular process resulting endonuclease cleavage of DNA into fragments and nucleosomal ladders. The effect of the aqueous leaf extract by Ipomoea sepiaria (family: Convolvulaceae) on PC-3 cell lines were tested for the assessment of toxicity levels at the biochemical level for apoptosis. There is no toxic effect on normal cells as there is no DNA fragmentation observed when the gels in $2 \mu M$ and 10 $\mu M$ extracts treated with PC-3. The RT-PCR MDRI and $T N F \alpha$ primes yielded product of $246 b p$ based on comparing bands by the primer. The proteins has shown functional relationships with tumor necrosis factor-mediated signaling pathway, cellular response to tumor necrosis factor, death-inducing signaling complex assembly, regulation of response to external stimulus and extrinsic apoptotic signaling pathway. Studies on DNA Ladder and cleavage through RT-PCR and protein interactions shows the presence of relationships and signaling process between MDRI and TNF alpha.
\end{abstract}

Keywords: PC-3, TNF alpha, MDR-1, Ipomoea sepiaria

\section{INTRODUCTION}

Breast and prostate cancers are preferably metastasize in the skeleton and boost bone desorption by osteoclasts. Alendronate pretreatment very effectively inhibited in vitro invasion of prostate cancer cells and play a possible role of the mevalonate pathway in invasion and migration of PC-3 cells [1] As per Lansky et al., 2005 experimental reports, Human PC-3 prostate cancer cells are inhibited at gross dosage $(4 \mu \mathrm{g} / \mathrm{ml})$ from aqueous compartments or oily compartment of pomegranate fruit (Punica granatum) [2]. Antisense oligodeoxynucleotides (ASODNs) when targeted against Testosterone-repressed prostate message-2 (TRPM-2) enhance chemosensitivity in human androgen-independent prostate cancer PC-3 cells [3].

The polyphenol-rich sweet potato greens [Ipomoea batatas leaves or greens] extract (SPGE) exerts considerable antiproliferative activity with prostate cancer cell lines through normal prostate epithelial cells [4]. In both in vitro and in vivo experimentation methods, SPGE perturbed cell cycle progression shows reduced modulated cell cycle, apoptosis regulatory molecules, clonogenic survival and induced apoptosis in human prostate cancer PC-3 cells.

In the present decades, medicinal plants are considered as one of the medicinal source plants which are having minimum side effects and having natural cure [5, 6]. Ipomoea sepiaria (I. sepiaria), an important ethanomedicinal plant [7], onsidered as a source plant in classical Ayurvedic drug Lakshmana known for the treatment of leucorrhoea and infertility [8]. Aqueous hot water extract of Bankalmi (Ipomoea sepiaria) is also efficiently used in the control of hispa beetle [9], bean aphid Aphis craccivora Koch [10], pulse beetle -Callosobruchus maculates [11]. Etc. There are no reports on Ipomoea sepiaria as anticancer agents for MCF-7 and PC-3 cell lines 
Dna Laddering, Rt-Pcr and in Silico Interaction Studies for Aqueous Leaf Extracts of Ipomoea Sepiaria as Anticancer Agents Towards Pc-3 Cell Lines

\section{Materials AND MethodS}

\subsection{Collection of Plant Material}

Fresh leaves of Ipomoea sepiaria were collected from surrounding areas of Visakhapatnam, India. The dust particles were removed by washing leaves of Ipomoea sepiaria with double distilled water. The leaves were shade dried and then grounded to powder using mortar and pestle. The obtained powdered samples were then stored in an airtight closed bottle and were used for further experiments.

\subsection{Preparation of Plant Extract of Ipomoea Sepiaria}

About 20gms of the plant powder of Ipomoea sepiaria was taken in $250 \mathrm{ml}$ Erlenmeyer flask. The material was boiled with $100 \mathrm{ml}$ of double distilled water, filtered with Whatman Filter paper no. 1 after cooling and was stored at $4^{\circ} \mathrm{C}$ for further experimentation.

\subsection{Dna Laddering on Ipomoea Sepiaria Treated Lymphocytes}

DNA Laddering was performed to identify the toxicity levels of the DNA formulation by Ipomoea sepiaria on normal cells. Fresh healthy blood sample was collected and the lymphocytes were treated with DNA-formulated Ipomoea sepiaria with two different concentrations of 2 and $10 \mu \mathrm{M}$ and incubated at $37^{\circ} \mathrm{C}$ for $48-96$ hours. DNA was isolated by simple, rapid, nonenzymatic method [12]. Gel Electrophoresis was performed using $1 \%$ agarose gel $(1.0 \mathrm{gm}$ of agarose in $100 \mathrm{ml}$ TEB $1 \mathrm{X}$ buffer) the gel was observe. Cell were grown and checked for the expression drug resistant markers using reverse transcriptase PCR (RT-PCR).

\subsection{Reverse Transcription PCR}

From the extract, mRNA was isolated using Trizol solution. Freshly prepared cDNA was synthesized from mRNA using cDNA Synthesis Kit (dNTP mixture). The obtained cDNA samples were subjected to PCR amplification with primers selective for mdr1 gene. As an internal control, the GAPDH gene was used for comparison. The reactions were performed with hot start at $95^{\circ} \mathrm{C}$ for denaturation, $60^{\circ} \mathrm{C}$ for annealing, and $72^{\circ} \mathrm{C}$ for amplification for 35 cycles. The amplified products were resolved on 1.5 $\%$ agarose gel and visualized by ethidium bromide staining, and the image recorded

\subsection{MDR 1 RT-PCR}

Primers were designed based on MDR1 sequences available in the GenBank database (accession no. M14758) with an online primer design software program (Primer 3).

For full-length MDR1 RT-PCR, primer sequences were

forward primer (1-20): 5'-ATGGATCTTGAAGGGGACCG-3'

reverse primer (3822-3842)): 5'- TCACTCCGCCTTTGTTCCAGC-3'

\section{Homo sapiens P-glycoprotein (PGY1) mRNA, complete cds 4,646 bp mRNA. Map: 7q21. \\ Accession: M14758.1 Gl: 187468}

\subsection{TNF alpha RT-PCR}

TNF alpha is an protein coding gene type that plays an important role in apoptosis is a popular housekeeping_standard_used in gene expression and Genbank studies.

For full-length TNF alpha RT-PCR, primer sequences were

\section{TNF alpha - Forward primer - ACT GAA CTT CGG GGT GAT TG \\ TNF alpha - Reverse primer - GCT TGG TGG TTT GCT ACG AC}


Dna Laddering, Rt-Pcr and in Silico Interaction Studies for Aqueous Leaf Extracts of Ipomoea Sepiaria as Anticancer Agents Towards Pc-3 Cell Lines

\section{TNF tumor necrosis factor [ Homo sapiens (human)]}

Gene ID: 7124, updated on 8-May-2017

summary

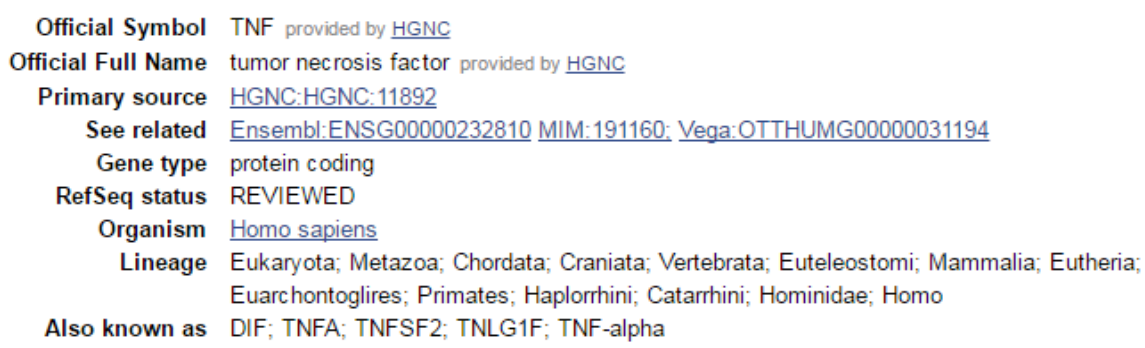

\subsection{Protein-Protein Interaction}

String database (https://string-db.org/) is used for understanding protein-protein interaction studies.

\section{RESULTS AND DISCUSSION}

The effect of the aqueous extract by Ipomoea sepiaria on PC-3 cell lines were tested for the assessment of toxicity levels at the biochemical level for apoptosis. Submarine gel electrophoresis provides a rapid and convenient way to check the quality of DNA and its physical state. Electrophoresis analysis of DNA using agarose gel can confirm DNA integrity. Smears on gel indicate fragmented DNA and intact DNA will give a clear band (Marker).

Figure 1 show that there is no toxic effect on normal cells as there is no DNA fragmentation observed in the gels in $2 \mu \mathrm{M}$ and $10 \mu \mathrm{M}$ extracts treated with PC-3 cell lines.
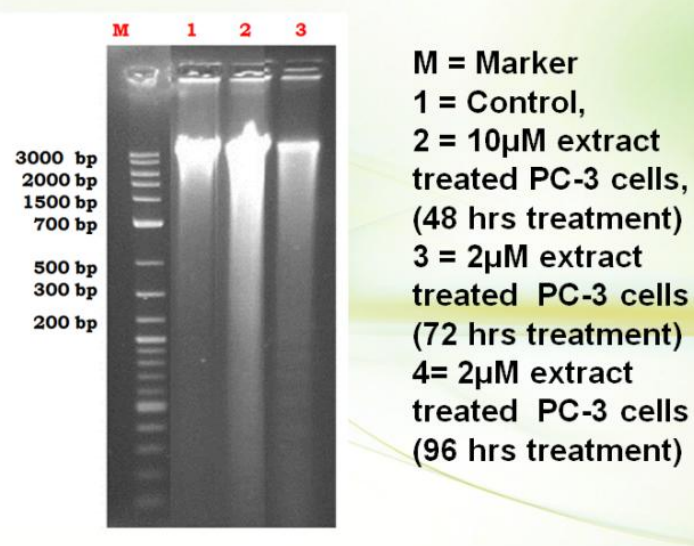

Figure1. DNA Fragmentation of aqueous extract by Ipomoea sepiaria on PC-3 cell lines

The expression levels of mRNAs for MDR1 (P-glycoprotein), with $\mathrm{TNF} \alpha$ stability increased RNA levels in all the drug-resistant cell lines. The RT-PCR MDR1, TNF $\alpha$ primes yielded product of 246bp (Figure 2).

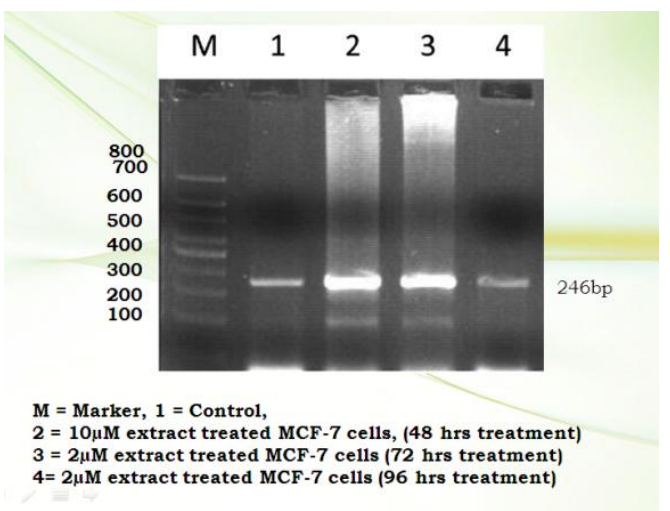

Figure2. Reverse transcription PCR for $\mathrm{TNF} \alpha$ 


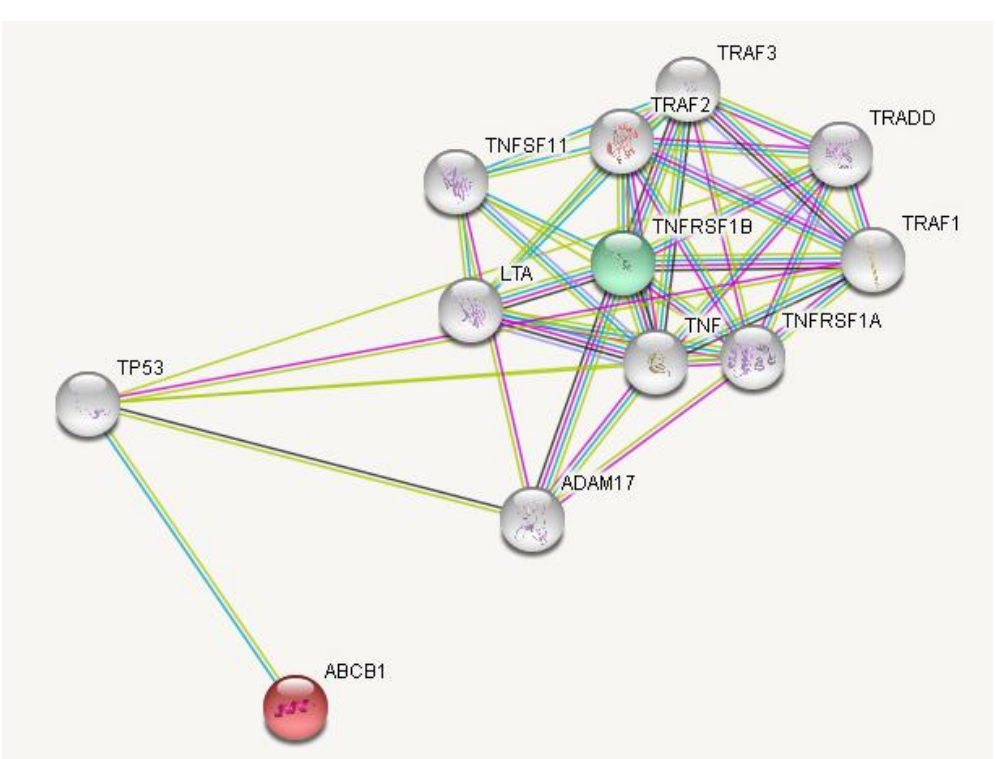

Figure3. Protein interaction studies for MDRI (or ABCB1) and TNF alpha

Figure 3 shows the protein interaction studies for MDR1 (or ABCB1) and TNF alpha with other proteins like Tumor protein p53 [Acts as a tumor suppressor in many tumor types; induces growth arrest or apoptosis depending on the physiological circumstances and cell type], TNF receptorassociated factor 1 [Adapter molecule that regulates the activation of NF- kappa-B and JNK], ADAM metallopeptidase domain 17 [Cleaves the membrane-bound precursor of TNF-alpha to its mature soluble form] and TNFRSF1A-associated via death domain [The nuclear form acts as a tumor suppressor by preventing ubiquitination and degradation of isoform p19ARF/ARF of CDKN2A by TRIP12]. The proteins has shown functional relationships with tumor necrosis factor-mediated signaling pathway, cellular response to tumor necrosis factor, death-inducing signaling complex assembly, regulation of response to external stimulus and extrinsic apoptotic signaling pathway. Studies on DNA Ladder and cleavage through RT-PCR and protein interactions shows the presence of relationships and signaling process between MDR1 and TNF alpha.

\section{ACKNOWLEDGEMENTS}

The authors would like to thank JNTUH and Bilaspur University for providing necessary facilities, financial support and technical assistance in bringing out the research work.

\section{REFERENCES}

[1] Virtanen S. S., Väänänen H. K., Härkönen P. L. and Lakkakorpi P. T., Alendronate inhibits invasion of PC-3 prostate cancer cells by affecting the mevalonate pathway, Cancer research 62(9), 2708-2714 (2002).

[2] Lansky E. P., Harrison G., Froom, P. and Jiang W. G., Pomegranate (Punica granatum) pure chemicals show possible synergistic inhibition of human PC-3 prostate cancer cell invasion across Matrigel ${ }^{\mathrm{TM}}$, Investigational new drugs 23(2), 121-122 (2005).

[3] Miyake H., Chi K. N. and Gleave M. E., Antisense TRPM-2 oligodeoxynucleotides chemosensitize human androgen-independent PC-3 prostate cancer cells both in vitro and in vivo, Clinical Cancer Research 6(5), 1655-1663 (2000).

[4] Karna P., Gundala S. R., Gupta M. V., Shamsi S. A., Pace R. D., Yates C., Narayan S. and Aneja, R., Polyphenol-rich sweet potato greens extract inhibits proliferation and induces apoptosis in prostate cancer cells in vitro and in vivo, Carcinogenesis 32(12), 1872-1880 (2011).

[5] Kaladhar D. S. V. G. K., Satyanarayana K. V. V. V. and Reddy B., Biochemical and antimicrobial studies of the genus Jatropha excisel, Biosciences, Biotechnology Research Asia 6(1), 331-336 (2009).

[6] DSVGK K., Saranya K. S., Vadlapudi V. and Yarla N. S., Evaluation of Anti-inflammatory and Antiproliferative Activity of Abutilon indicum L. Plant Ethanolic Leaf Extract on Lung Cancer Cell Line A549 for System Network Studies, J Cancer Sci Ther. 6, 195-201 (2014).

[7] Cheruvathur M. K., Abraham J. and Thomas T. D., In vitro micropropagation and flowering in Ipomoea sepiaria Roxb. An important ethanomedicinal plant, Asian Pacific Journal of Reproduction 4(1), 49-53 (2015). 
Dna Laddering, Rt-Pcr and in Silico Interaction Studies for Aqueous Leaf Extracts of Ipomoea Sepiaria as Anticancer Agents Towards Pc-3 Cell Lines

[8] Sayani M., Ashok B. K. and Nishteswar K., Phytochemical and antifungal studies on root of Ipomoea sepiaria Koenig Ex. Roxb, Global Journal of Research on Medicinal Plants \& Indigenous Medicine. 1(8), 372 (2012).

[9] Rahman S. S., Rahman M., Begum S. A., Khan M. M. R. and Bhuiyan M. H., Investigation of Sapindus mukorossi extracts for repellency, insecticidal activity and plant growth regulatory effect, J Appl Sci Res. 3, 95-101 (2007).

[10] Das B. C., Sarker P. K. and Rahman M. M., Aphidicidal activity of some indigenous plant extracts against bean aphid Aphis craccivora Koch (Homoptera: Aphididae), Journal of Pest Science 81(3), 153-159 (2008).

[11] Rahman A. and Talukder F. A., Bioefficacy of some plant derivatives that protect grain against the pulse beetle, Callosobruchus maculates, Journal of Insect Science 6(1), 3 (2006).

[12] Lahiri D K, Nurnberger Jr J I., A rapid non-enzymatic method for the preparation of HMW DNA from blood for RFLP studies, Nucleic acids research 19(19), 5444 (1991).

Citation: S. Meesala, "Dna Laddering, Rt-Pcr and in Silico Interaction Studies for Aqueous Leaf Extracts of Ipomoea Sepiaria as Anticancer Agents Towards Pc-3 Cell Lines", International Journal of Research Studies in Biosciences (IJRSB), vol. 5, no. 9, pp. 11-15, 2017. http://dx.doi.org/10.20431/2349-0365.0509003

Copyright: (C) 2017 Authors. This is an open-access article distributed under the terms of the Creative Commons Attribution License, which permits unrestricted use, distribution, and reproduction in any medium, provided the original author and source are credited. 